OPINION PIECE

\title{
Emotion and Partnerships
}

Peter Felten, Center for Engaged Learning, Elon University, North Carolina, United States Contact: pfelten@elon.edu

I have a confession to make. This feels a bit risky to do in a scholarly journal, but here goes: Every partnership I have been a part of has been an emotional experience.

Does that shock you? Probably not. Personal partnerships are rooted in emotions; I feel joy when my spouse smiles and sadness when my basketball teammate is injured. The professional relationships of student-faculty partnerships are also emotional, although firstyear undergraduates may feel different things than senior academics as they navigate a partnership. Yet the scholarly literature on partnerships virtually ignores emotion. That is unfortunate because both the practices we use and the research we conduct could be deepened by directly addressing the ways emotions influence partnership processes and outcomes.

\section{EMOTION IN THE LITERATURE ON PARTNERSHIPS}

In preparation for a comprehensive literature review on students-as-partners, an international group recently compiled a database of more than 380 scholarly articles related to this topic (Mercer-Mapstone, Dvorakova, Matthews, Abbot, Cheng, Felten, Knorr, Marquis, Shammas, \& Swaim, 2017). Nearly 75\% of these publications have appeared since 2010 as partnership has spread across higher education in many countries, although the earliest was published in 1969. The word "emotion" (or any variation or synonym for that word) appears only once among the nearly 5,300 words in the titles of those publications. Of course, titles do not tell the whole story, but scholars typically use titles to convey the essential themes and topics of their work. Systematic absence in the scholarly literature suggests that emotion is not a commonly studied facet of partnership.

A deeper dive into two of the most widely cited recent works on partnership also suggests that emotion is an under-studied topic in the literature. Healey, Flint, and Harrington (2014) cite a psychological framework to explain that "shared emotional connection" (p. 28) is an essential element in partnerships. They later summarize two reports on student unions and higher education institutions to note that partner relationships help students "feel emotionally invested and empowered" (p. 30). The word "emotion" appears even less often in Cook-Sather, Bovill, and Felten (2014), although these authors, like Healey and colleagues, delve into issues linked to emotions, including feelings of risk and discomfort evoked by liminality and also the tensions within relationships that can be exacerbated by power differentials. 
Emotion is not always absent from the partnership literature, however. It seems to appear most directly and frequently in personal reflections written about partnerships. For instance, Alter (2012) calls her undergraduate partnership "an intense and often emotional experience" (p. 1), and Powers (2012), drawing lessons from partnerships she and her student peers engaged in, concludes: "While it can be tempting to try to rush relationships and jump ahead to a place where two people feel completely comfortable with one another and able to express a diverse range of emotions and perspectives, it is not realistic if the relationship is to develop a strong foundation" (p. 8). Scholars and theorists have noted what Mann (2008) calls the "rich emotional texture" (p. 96) of student reflections on their educational experiences, and the literature on student engagement also emphasizes the centrality of emotion in learning (Bryson, 2014; Kahu, 2013; Bovill, Cook-Sather, Felten, Millard, \& Moore-Cherry, 2016; see also Shor, 1992).

In traditional scholarly publications, faculty and academic staff often describe their partnerships in unemotional terms: "Meeting once a week with a student consultant is an intense exercise in self-reflection" (quoted in Felten, 2011, p. 1). When writing more personal and reflective essays, however, they also emphasize the emotional aspects of partnership. Describing a semester-long collaboration with an undergraduate, a senior male academic noted: "[You gain] confidence not just in the classroom, not just in your office and on campus, but also off campus, at home. I feel a kind of peace in my heart, not anxiety" (quoted in CookSather \& Abbot, 2016). Reflecting on a similar partnership, a junior female staff member explained:

Before I began meeting with my consultant, I have to admit that the prospect of opening my classroom to the critique of another was intimidating. I felt vulnerable and more self-conscious about my teaching than I ever have before; however, now when I think back on my experiences with my consultant, the sole feeling that washes over me is gratitude. (Conner, 2012, p. 8)

Emotion clearly is a component of student-faculty partnerships, yet academic customsincluding our scholarly forms of writing-privilege the rational. That narrow focus obscures important aspects of partnership.

\section{THE NECESSITY OF EMOTION}

Over the past 30 years, psychologists and neuroscientists have demonstrated that the traditional Western view that separates thinking from feeling is wrong: "A purely cognitive view of the mind, one that overlooks the role of emotions, simply won't do" (LeDoux, 2002, p. 200). Unlike traits or moods, emotions are relatively brief and context-specific responses to experiences, objects, or causes. This means that "emotions orient people to respond to ongoing events in their environment" and are always "relational" (Keltner \& Lerner, 2010, p. 318). By playing this foundational role in human behavior, emotions "structure relations ... [and] guide social interactions," organizing "the interactions of individuals in meaningful relationships" (Keltner \& Haidt, 1999, pp. 506, 510). Emotions also shape (a) what people tend to think about, (b) how deeply and critically they engage with ideas and experiences, and (c) the goals and 
motivations that inhibit or enable behaviors (Lerner, Li, Valdesolo, \& Kassam, 2015). That's a citation-heavy way of making two fundamental claims:

1. We cannot understand the experiences of or outcomes for individuals in partnerships without attending to emotions.

2. We cannot understand the interactions and relationships between individuals in partnerships without attending to emotions.

\section{EMOTION AND PARTNERSHIP}

A first step toward honoring the influence of emotion in partnership involves what Gestalt Theory refers to as the figure-ground principle. In short, when we look at or study something, we tend to focus on certain aspects, "figure," and not other things that are present, "ground" (Knewstubb \& Ruth, 2016). Scholars of partnerships often treat issues of power as figure in these relationships; for instance, Healey, Flint, and Harrington (2014) contend that "the distribution of power and responsibility is seen as one of the fundamental features of partnership" (p. 31), while Cook-Sather, Bovill, and Felten (2014) refer to "power dynamics" as perhaps "the most critical dimension of this work" (p. 137). Power certainly merits careful analysis, but we may learn new things by switching our gaze to the emotional "ground" of partnerships.

The scholarship in our emerging field is ripe for such a move because so much of our research is rooted in the perspectives and voices of those who are working together in partnership. We may not need to ask radically different research questions or use new methodologies in our inquiries; instead, we simply might turn our gaze to the emotional experiences and the "layered learning" (Cook-Sather, 2011) that are occurring before our eyes. Although bringing emotion into focus may feel more radical in some disciplines and contexts, even in these cases the psychological research cited briefly above may provide a scientific path into this line of inquiry. Regardless of the methods used, student-faculty teams should be an especially effective approach to this type of research because any analysis will benefit from multiple perspectives on the complex intersections of identities and relational dynamics that unfold in every partnership (Cook-Sather, 2014).

Ironically, a figure-ground shift might be more comfortable for scholars than for some practitioners in partnerships. While many of us already may discuss the emotional component of our collaborations, some partners feel wary about explicitly addressing the emotions that arise. Faculty, for instance, may not feel prepared to help students navigate the emotions they experience in challenging learning environments (Felten, Gilchrist, \& Darby, 2006). This caution is valid but can be managed by attending first to the positive emotions that motivate students and faculty to engage together in partnership. Through honest but low-stakes dialogue about the excitement-and the nervousness - that characterize the initial stages of a collaboration, partners build a foundation for deeper engagement with emotions in the relationship.

Focusing on the emotional dimensions of partnerships will shine new light on the dynamic processes and the powerful outcomes of this work. By bringing emotion out of the background, we will be more effective as partners and more critical as scholars. 


\section{NOTE ON CONTRIBUTOR}

Peter Felten is assistant provost for teaching and learning, executive director of the Center for Engaged Learning, and professor of history at Elon University.

\section{REFERENCES}

Alter, Z. (2012). Discerning growth: Lessons from one TLI partnership. Teaching and Learning Together in Higher Education, 1(6), 1-3. http://repository.brynmawr.edu/tlthe/vol1/iss6/3

Bovill, C., Cook-Sather, A., Felten, P., Millard, L., \& Moore-Cherry, N. (2016). Addressing potential challenges in co-creating learning and teaching. Higher Education, 71(2), 195208. doi:10.1007/s10734-015-9896-4

Bryson, C., ed. (2014). Understanding and Developing Student Engagement. New York: Routledge.

Conner, J. (2012). Steps in walking the talk: How working with a student consultant helped me integrate student voice more fully into my pedagogical planning and practice. Teaching and Learning Together in Higher Education, 1(6), 1-8. http://repository.brynmawr.edu/tlthe/vol1/iss6/6

Cook-Sather, A. (2011). Layered learning. Educational Action Research, 19(1), 41-57. http://dx.doi.org/10.1080/09650792.2011.547680

Cook-Sather, A. (2014). Multiplying perspectives and improving practice. Instructional Science, 42, 31-46. http://repository.brynmawr.edu/edu_pubs/28

Cook-Sather, A., \& Abbot, S. (2016). Translating partnerships: How faculty-student collaboration in explorations of teaching and learning can transform perceptions, terms, and selves. Teaching \& Learning Inquiry, 4(2), 1-13. http://dx.doi.org/10.20343/10.20343/teachlearninqu.4.2.5

Cook-Sather, A., Bovill, C., \& Felten P. (2014). Engaging students as partners in learning and teaching: A guide for faculty. San Francisco: Jossey-Bass.

Felten, P. (2011). Monet moments and the necessity of productive disruption. Teaching and Learning Together in Higher Education, 1(2), 1-2. http://repository.brynmawr.edu/tlthe/vol1/iss2/1

Felten, P., Gilchrist, L., \& Darby, A. (2006). Emotion and learning. Michigan Journal of Community Service Learning, 12(2), 38-46. http://hdl.handle.net/2027/spo.3239521.0012.204

Healey, M., Flint, A., \& Harrington, K. (2014). Engagement through partnerships: Students as partners in learning and teaching in higher education. York: Higher Education Academy. Retrieved from https://www.heacademy.ac.uk/sites/default/files/resources/engagement through part nership.pdf

Kahu, E. (2013). Framing student engagement in higher education. Studies in Higher Education, 38(5), 758-773. http://dx.doi.org/10.1080/03075079.2011.598505

Keltner, D., \& Haidt, J. (1999). Social functions of emotions at four levels of analysis. Cognition 
and Emotion, 13(5), 505-521. http://dx.doi.org/10.1080/026999399379168

Keltner, D., \& Lerner, J. (2010). Emotion. In S. Fiske, D. Gilbert, \& G. Lindzey (Eds.), Handbook of Social Psychology, Fifth Edition (317-352). San Francisco: Wiley.

Knewstubb, B., \& Ruth, A. (2015). Gestalt and figure-ground. International Journal for Academic Development, 20(1), 4-17. http://dx.doi.org/10.1080/1360144X.2014.946931

LeDoux, J. (2002). Synaptic Self. New York: Viking.

Lerner, J., Li, Y., Valdesolo, P., \& Kassam, K. (2015). Emotion and decision making. Annual Review of Psychology, 66, 799-823.

http://www.annualreviews.org/doi/10.1146/annurev-psych-010213-115043

Mann, S. (2008). Study, power, and the university. Maidenhead: Open University Press.

Mercer-Mapstone, L., Dvorakova, S., Matthews, K., Abbot, S., Cheng, B., Felten, P., Knorr, K., Marquis, E., Shammas, R., \& Swaim, K. (2017). A systematic literature review of students as partners in higher education. International Journal for Students as Partners 1:1. https://mulpress.mcmaster.ca/ijsap/article/view/3119/2751

Powers, M. (2012). From the student perspective: Reflections on seven core principles of facilitating faculty-student partnerships within an educational initiative. Teaching and Learning Together in Higher Education, 1(7), 1-8. http://repository.brynmawr.edu/tlthe/vol1/iss7/9

Shor, I. (1992). Empowering Education. Chicago: University of Chicago Press. 